
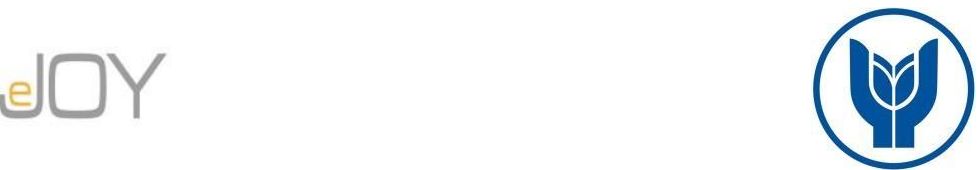

Cihangir, M., Polat, M. A., Çalışkan, U. / Journal of Yasar University, 2020, 15/60, 920-940

\title{
Türkiye'de Alternatif Finansal Yatırım Araçları Arasındaki Dinamik Etkileşim: Uygulamalı Bir Analiz
}

\section{Dynamic Interaction among Alternative Financial Investment Instruments in Turkey: An Empirical Analysis}

\author{
Mehmet CİHANGİR, Osmaniye Korkut Ata Üniversitesi, Türkiye, cihangir@osmaniye.edu.tr \\ Orcid No: 0000-0002-3375-6408 \\ Mehmet Ali POLAT, Malatya Turgut Özal Üniversitesi, Türkiye, mehmet.polat@ozal.edu.tr \\ Orcid No: 0000-0001-9239-8228
}

Uğraş ÇALIŞKAN, Osmaniye Korkut Ata Üniversitesi, Türkiye, ugrascaliskan@ hotmail.com.tr

Orcid No: 0000-0002-4942-8732

\begin{abstract}
Öz: Bu çalıșmada; Türkiye'de altın, borsa, döviz ve faiz getirileri arasındaki etkileşim, 2002:M01-2019:M11 dönemi için VAR yöntemiyle incelenmiştir. Etki-tepki fonksiyonlarına göre dövizin getirisi arttığında; borsa, altın ve faiz de artmış, altının getirisi arttı̆̆ında; borsa, altın ve faiz ilk dönemde artmış, sonra döviz ve altın azalmaya başlamıştır. Borsanın getirisi azaldı̆̆ında; altın, döviz ve faiz ilk dönemde azalmış, sonra artmaya başlamıştır. Faizler arttığındaysa; borsa, altın ve döviz azalmaya başlamıştır. Varyans ayrıştırması analizinde; faizdeki değişimlerin \%31'inin dövizden, \%10.8'inin altından, \%3.8'inin borsadan kaynaklandığl, altın fiyatlarındaki değişimlerin \%10.2'sinin döviz, \%2.3'ünün borsa kaynaklı olduğu, borsanın getirisinde yaşanan değişimlerin \%7.8'inin altından kaynaklandı̆̆ ortaya çıkmıştır. Dövizin getirisinde meydana gelen değişimlerin\%38'inin altında, \%14'ünün borsada ve \%1.3'ünün faizde meydana gelen değişimlerden kaynaklandı̆ğ görülmüş̧ür. Seriler arasindaki nedensellik ilişkileri Granger testiyle incelenmiş ve dövizden altına; altın, borsa ve dövizden faize; borsadan dövize doğru tek yönlü nedensellik ilişkileri bulunmuştur.
\end{abstract}

\section{Anahtar Sözcükler: Finansal Yatırım Araçları, Vektör Otoregresif Model, Nedensellik Analizi}

JEL Sinıflandırması: 016, D14, G11

\begin{abstract}
In this study, the interactions among the return of gold, stock market, exchange rate and interest are analyzed by VAR method for 2002:M01-2019:M11 period. According to impulse-response functions; when the return on exchange rate rises, stock exchange, gold and interest increase and when the return on gold rises, stock exchange, gold and interest increase in the first period and then exchange rate and interest started to decrease. When the stock market's return decreases; gold, exchange rate and interest rate began to decrease. Moreover, when interest rates increase; stock market, gold and exchange rate began to decline in variance decomposition analysis, it is revealed that \%31 of the changes in interest is resulted by exchange rate, \%10.8 is by gold and \%3.8 is by stock exchange. In addition, \%10.2 of the changes in gold prices is by exchange rate, $\% 2.3$ is by stock exchange and \%7.8 of the changes in return of stock exchange is resulted by gold. It is seen that $\% 38$ of the changes in exchange rate is due to the change in gold, \%14 of it is due to stock exchange and \% 1.3 is due to interest. Causality relationships between the series are examined by Granger test and one-way causality relationships are found from exchange rate to gold, from gold, stock exchange and exchange rate to interest; from stock exchange to exchange rate.
\end{abstract}

Key Words: Financial Investment Instruments, Vector Autoregressive Model, Causality Analysis

JEL Classification: 016, D14, G11

Makale Gecmiși / Article History

Başvuru Tarihi / Date of Application

Kabul Tarihi / Acceptance Date

: 22 Haziran / June 2020

: 14 Ekim / October 2020

(C) 2020 Journal of Yaşar University. Published by Yaşar University. Journal of Yaşar University is an open access journal.

There is no conflict of interest or ethical concern regarding this publication. 


\section{Giriş}

Türkiye ekonomisinde, yurtiçi yatırımların uzun süredir yurtiçi tasarruflarla finanse edilememesi, ülkenin dış borç yükünü artmaktadır. 2019 yılsonu itibariyle, Türkiye'nin toplam diş borç stoku 446 milyar Dolara ulaşmıştır (EVDS, 2019a). Bu sorunun en önemli nedenlerinden biri; tasarruf sahiplerine, güvenilir ve reel getirisi yüksek yatırım araçlarının sunulamamış olmasıdır. Yurtiçi tasarrufları artırabilmek için kurulan ve çalışanlar için zorunlu hale getirilen BES (Bireysel Emeklilik Sistemi)'nin yeterince başarılı olamamasının ve bu sisteme zorunlu olarak dâhil edilen kişilerin büyük çoğunluğunun kısa sürede sistemden çıkış yapmalarının (Doğan, 2018) önemli bir nedeni de, bu birikimlerin doğru yatırım portföylerinde değerlendirilememesi ve bu tasarrufların enflasyon karşısında değer kaybediyor olmasıdır. Bu nedenle Türkiye'deki tasarruf sahipleri fonlarını; altın, döviz, borsa ve vadeli mevduatlarda değerlendirmeyi tercih etmekte ve genellikle portföylerinde bu yatırım araçlarını bulundurmaktadırlar. Ancak bu yatırım araçlarının sahip olduğu yüksek oynaklık ve aralarındaki dinamik etkileşim, bireyleri ve kurumları, tasarruflarını değerlendirme kararları konusunda zor durumda bırakabilmektedir.

Tasarruf sahiplerine yeterince yüksek ve istikrarlı reel getiri sunamayan ülkelerde yurtiçi tasarruflar düşük seviyelerde kalabilmektedir. Yurtiçi tasarruf oranlarının düşüklüğü ise ülkelerin tasarruf-yatırım açığı vermelerine neden olmaktadır. Bu açık, cari işlemler açığını da artırmaktadır. Çünkü alınan borçların faiz ödemeleri, cari işlemler hesabına kaydedilmektedir (TCMB, 2015). Artan cari açık ise ülkeleri ekonomik krizlere sürükleme potansiyeline sahip, çok önemli bir makroekonomik değişkendir (Polat, 2019). Özellikle Türkiye'de yaşanan 1994 ve 2001 ekonomik krizlerinin önemli bir nedeni, cari işlemler açığındaki artışlardır. Bu nedenle; ülkede tasarrufları artırabilmek için finansal kurum temsilcilerine ve ekonomi politikalarına yön veren erklere düşen görev; gerekli önlemlerin ivedilikle alınması, araştırmacılara düşen sorumluluk da alternatif yatırım araçlarının getirilerinin ve birbirlerinden etkilenme derecelerinin, analizlerle ortaya konularak, tasarruf sahiplerine rehberlik edilmesidir.

$\mathrm{Bu}$ çalışma ile amaçlanan, Türkiye'de hane halkı ve firmaların tasarruflarını değerlendirmekte sıklıkla başvurdukları; döviz, altın, vadeli mevduat ve borsanın getirilerini, 2002:M01-2019:M11 dönemi için eşanlı olarak analiz etmek ve elde edilecek bulgular üzerinden, tasarruf sahiplerine ve politika yapıcılara yol göstermektir. Çalışmanın ikinci bölümünde; tasarruflarla ilgili teorik çerçeveye yer verilmiş, üçüncü bölümünde; Türkiye'deki tasarruf ve yatırım düzeyleri ve bu büyüklükler arasındaki açı̆̆ın cari işlemler dengesi üzerindeki etkileri grafikler yardımıyla incelenmiştir. Dördüncü bölümde; literatür özeti sunulmuş, beşinci bölümde ekonometrik analizler gerçekleştirilmiştir. Sonuç ve politika önerileri ile çalışma tamamlanmıştır. Çalışmanın ele aldığı konu, bu konuyu irdeleme biçimi, kullanılan veri seti ve analiz yöntemleriyle literatüre ve ülke ekonomisine bir katkı sağlaması beklenmektedir. 


\section{Tasarruflarla İlgili Teorik Çerçeve}

Harrod (1939) ve Domar (1946) çalışmalarıyla geliştirilen Post Keynesyen Ekonomik Büyüme Modelinde; yatırımlar, ekonomik büyümenin en önemli dinamiği olarak ele alınmaktadır. $\mathrm{Bu}$ yaklaşımda; yatırımların $(I)$, tasarruflara $(S)$ eşit olduğu varsayılmakta, tasarruflar ise milli gelirin $(Y)$ bir fonksiyonu olarak açıklanmaktadır.

$$
S=\bar{S}+s Y
$$

Burada $\bar{S}$; otonom tasarruf miktarını, $s$; marjinal tasarruf oranını göstermektedir. Burada tasarruflar, gelirin artan bir fonksiyonu olup, gelir arttıkça, tasarruf edilen miktar da artacaktır. $\mathrm{Bu}$ fonksiyon, faizi de içerecek şekilde genişletilecek olursa;

$S=F(Y, i)$

şeklinde bir kapalı fonksiyona ulaş1lır. Burada tasarruflar; gelirin ve faizin artan bir fonksiyonudur (Eğilmez, 2013). Yani artan faiz oranları ile birlikte, fon sahipleri, ellerinde bulundurdukları varlıkları bugün harcamak yerine, şimdi tasarruf edip (vadeli mevduatta bekletip), belirli bir süre sonra, elde edecekleri faiz gelirleriyle birlikte, daha fazla harcamayı tercih edebileceklerdir. Keynes'e göre faiz; parayı tasarruf etmenin (likiditeden vazgeçmenin) bir ödülüdür (Öztürk ve Durgut, 2011: 112). Tabi bu mekanizmanın çalışabilmesi için tasarruf sahiplerine pozitif reel getiri sağlanması büyük önem taşımaktadır (Köse vd., 2015: 323).

Solow (1956) ve Swan (1956) tarafından geliştirilen Neo-Klasik Ekonomik Büyüme Modelinde de ekonomik büyümenin temel belirleyicisi olarak; işgücü başına düşen sabit sermaye stoku alınmakta, bunun için de yatırımların ve tasarrufların artırılmasının gerektiği ifade edilmektedir. Tasarrufların artırllabilmesi için ise; öngörülebilir düşük bir enflasyon düzeyi (TCMB, 2013), pozitif reel faizler (Bulut ve Karakaya, 2018), istikrarlı bir ekonomik ve siyası yapı gerekmektedir. Romer (1986) ve Lucas (1988)'in katkılarıyla geliştirilen İçsel Büyüme Modellerinde de beşeri sermayenin ve Araştırma - Geliştirme (Ar\&Ge) çalışmalarının artırılabilmesi için yurtiçi tasarruflar büyük öneme sahiptir (Tapşın, 2011).

Portföy Teorisine göre; sahip olunan finansal varlıkların, mümkün olduğunca az risk alınarak, en fazla getiriyi sağlayacak şekilde yatırım araçları arasında dağıtılması gerekmektedir. Markowitz (1952), tasarruf sahiplerinin, varlıklarını en mantıklı biçimde değerlendirmek istemelerini ve bunu yaparken de yatırımlarında minimum risk, maksimum getiri beklentisi içinde olmalarını, Optimal Portföy Teorisi ile açıklamaktadır (Yiğiter ve Akkaynak, 2017: 285). Bu noktada bilim insanlarına düşen görev; yurtiçi tasarrufların artırılabilmesi fon sahiplerine, doğru portföy yönetimi konusunda rehberlik etmektir.

\section{Türkiye'de Tasarruflar ve Tasarruf Araçları}

Türkiye'de 1980 öncesi dönemde kambiyo sistemi uygulanmıştır. Bu kapsamda tüzel kişilerin ve şirketlerin döviz kullanımları devlet kontrolüne tabi tutulmuş, dış ticaret oldukça sınırlı kalmış, üretimde ithal ikamesi modeli benimsenmiştir. Söz konusu dönemde bankalardan benlenen temel vazife; ülkenin sanayileşebilmesi için özel sektöre gerekli finansmanı sağlamak olmuştur. Genellikle negatif reel faizlerin söz konusu olduğu bu dönemde, 
bankacılık sektörü çoğunlukla büyük holdinglerin kontrolünde olmuş, özel mevduatlar oldukça düşük seviyelerde kalmıştır. Bireyler tasarruflarını genellikle altın ya da devlet tahvillerinde değerlendirmeyi tercih etmişlerdir (Özlale ve Karakurt, 2012: 9).

24 Ocak 1980 kararlarıyla birlikte ekonomide dışa açılma başlamış, ihracata dayalı ekonomik büyüme modeli benimsenmiştir. 3 Ocak 1986'da İstanbul Menkul Kıymetler Borsası (IMKB) kurulmuş, böylece tasarruf sahiplerine, hisse senedi alma imkânı doğmuştur (BIST, 2013). 11 Ağustos 1989'da kabul edilen Türk Parasının Kıymetini Koruma Hakkında 32 Sayılı Karar ile Türk Lirası konvertibl hale getirilmiş, kişi ve kurumların döviz bulundurmaları ve kullanımları serbest bırakılmıştır. Artık Türkiye'de finansal liberalizasyon başlamış, yabancı yatırımcıların İMKB'de veya Türkiye'deki bankalarda yatırım yapmalarına, Türkiye'deki yerleşiklerin de yurtdışında portföy oluşturmalarına izin verilmiştir. Böylece tasarruf sahipleri portföylerine; vadeli mevduat, altın ve hisse senedinin yanında, yabancı varlıkları da eklemeye başlamışlardır (Kılıç, 2012). 1990'lı yıllarda yüksek enflasyon ve buna bağlı olarak yüksek seyreden faiz oranları, hızla artan döviz kurları ve piyasa belirsizlikleri içinde geçmiştir. Ülke 1994 ve 2001 yıllarında, döviz kuru ve cari açık kaynaklı iki önemli ekonomik kriz yaşamış, 2001 krizinde 25 banka kapanmıştır. 1980 - 2019 dönemine Türkiye ekonomisindeki yurtiçi tasarrufların milli gelire oranı ve yatırımların milli gelire oranı verileri, Grafik 1'de yer almaktadır.

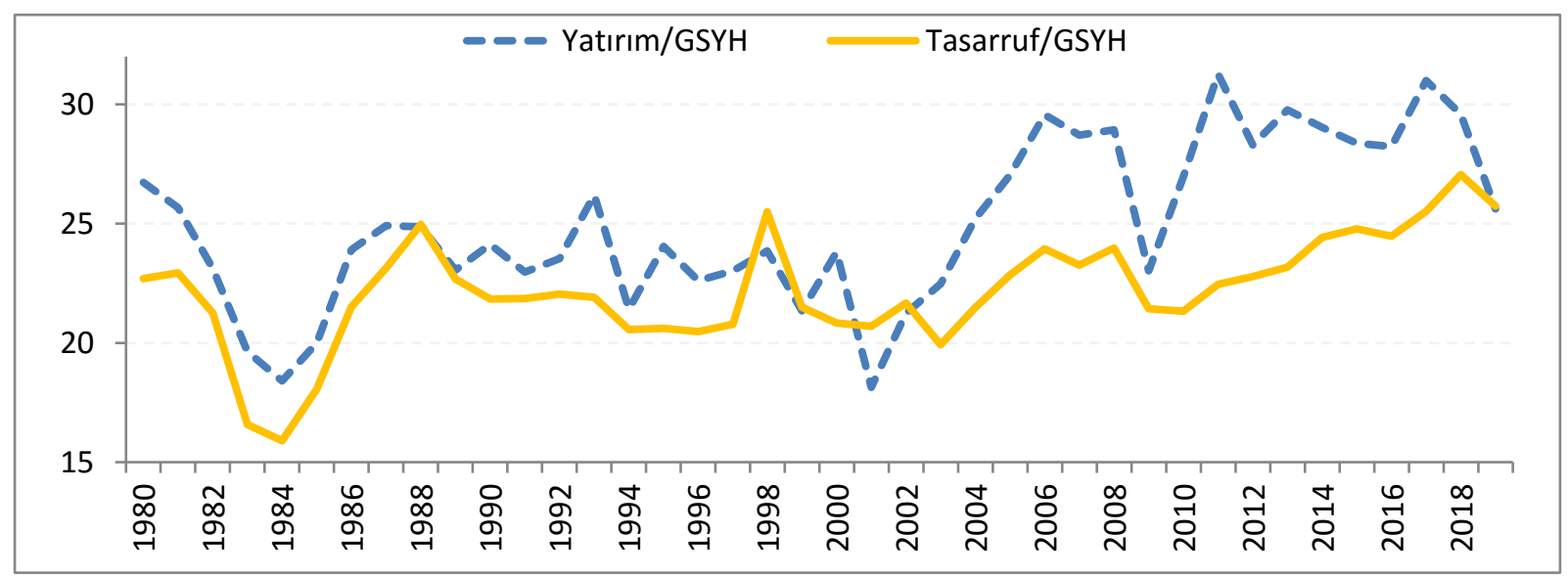

Grafik 1. Türkiye'de Tasarruf ve Yatırımlar

Kaynak: IMF (2019)'dan alınan veriler kullanılarak yazar tarafindan hazırlanmıştır.

Grafik 1'den de görüldüğü üzere; Türkiye'de genellikle tasarruflar, yatırımları finanse etmeye yetmemektedir. 1980 yılında tasarruflar milli gelirin \%23'ü, yatırımlar ise \%27'si civarındadır. 1998'de ilk defa tasarruflar, yatırımları aşmış, sonrasında yaşanan 2001 kriziyle birlikte yatırımlar önemli ölçüde azalmıştır. 2002 sonrası dönemde yatırımlar hızla artarken, tasarruflar düşük kalmıştır. 2008 kriziyle birlikte azalan bu değişkenler, sonrasında tekrar artmaya başlamış olsa da 2019 yılı itibariyle her ikisi de düşüş trendine girmiş gözükmektedir. Oluşan bu yatırım-tasarruf açığı, ülkedeki cari işlemler açığını da artırmaktadır. Çünkü alınan borçların faiz ödemeleri cari işlemler hesabına kaydedilmektedir (Göçer, 2013: 220). Tasarruf 
- yatırım açığının milli gelire oranı ile cari işlemler açığının milli gelire oranı arasındaki etkileşimler Grafik 2'den izlenebilir.

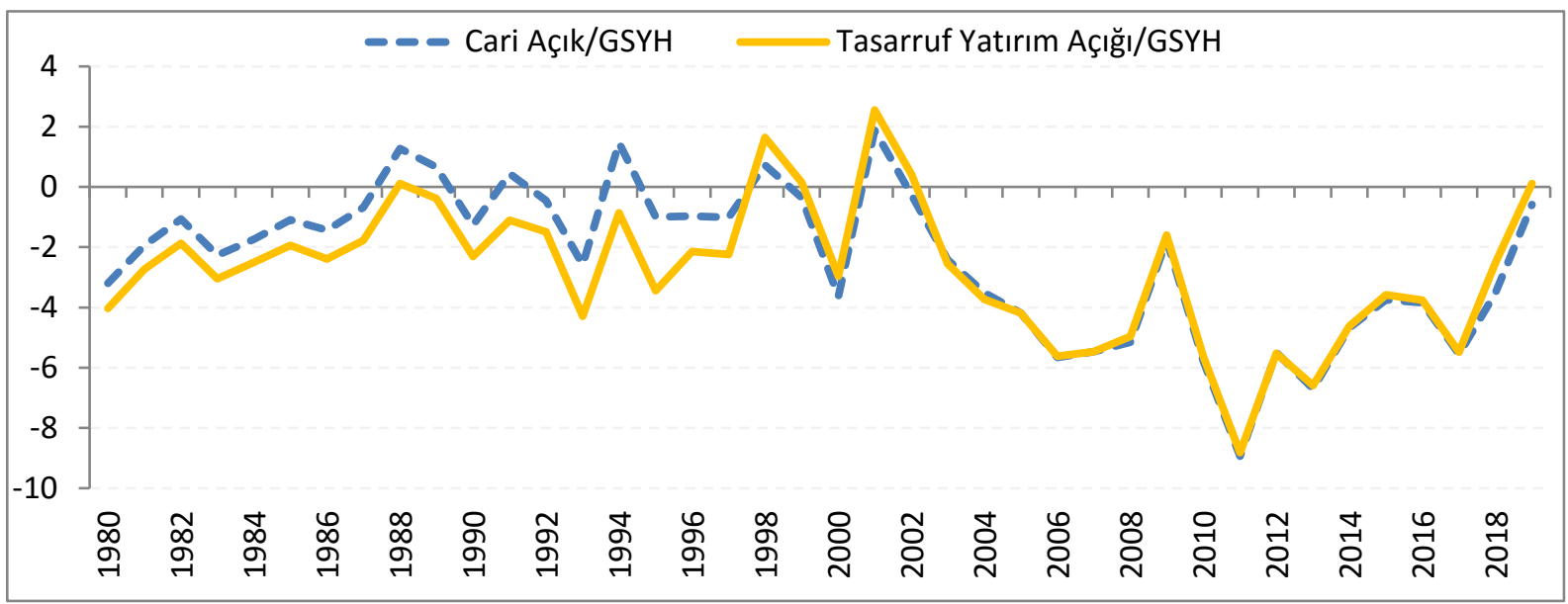

Grafik 2. Tasarruf - Yatırım Açı̆̆ı ile Cari İşlemler Açı̆̆ı arasındaki İlişki

Kaynak: IMF (2019)'dan alınan veriler kullanılarak yazar tarafından hazırlanmıştır.

Grafik 2'den de görüldüğü gibi; Türkiye'de tasarruf-yatırım açığı ile cari açık arasında oldukça güçlü bir ilişki vardır. Artan cari açık ise ülkeleri ekonomik krizlere sürükleme potansiyeline sahip önemli bir makroekonomik değişkendir (Polat, 2019). Bu bağlamda, özellikle Türkiye'de yaşanan 1994 ve 2001 ekonomik krizlerinin önemli bir nedeni, cari işlemler açığındaki artışlardır. Bu nedenle, kamu ve özel sektör işbirliği ile ülkedeki tasarrufların artırılması ve bu yolla cari açığın ve yeni ekonomik kriz risklerinin azaltılması gerekmektedir. Bu noktada; akademik olarak yatırım araçlarının getirilerinin kıyaslanması ve aralarındaki etkileşimlerin açıklanması da büyük önem taşımaktadır. Bu çalışma ile hedeflenen de budur.

\section{Literatür Özeti}

Yatırım araçları arasındaki etkileşime ilişkin literatürde yer alan çalışmalardan ulaşılabilenlerin kısa bir özeti, yayınlanma tarihi sırasına göre buraya alınmıştır. Bu çalışmalar seçilirken, özellikle ampirik analiz içeren çalışmalar olmaları tercih edilmiştir.

Levin vd. (2006), ABD'de altın ve hisse senedi fiyatları arasındaki etkileşimi, 1976-2005 dönemi için analiz etmiş ve aralarında pozitif bir ilişki belirlemiştir. Yani ABD piyasalarında hisse senetleri ile altın, birbirinin tamamlayıcısı konumundadır. Mishra vd. (2010), Hindistan'da altın fiyatları oynaklığı ile borsa getirileri arasındaki ilişkiyi, liberalizasyon çalışmalarının başladığı 1991 sonrası için, 1991-2009 dönemi verilerini kullanarak, Johansen eşbütünleşme testi ve Granger nedensellik testi yöntemiyle araştırmış ve bu serilerin uzun dönemde birlikte hareket ettiklerini ve aralarında karşılıklı nedensellik ilişkilerinin olduğunu tespit etmiştir.

Balı ve Cinel (2011), altın fiyatlarının İMKB100 endeksi üzerindeki etkilerini, 1995-2011 dönemi için incelemiştir. Altın ithalat tutarı, dış ticaret dengesi, faiz oranı, petrol fiyatı, petrol 
ithalat tutarı, tüketici fiyatları endeksi, bütçe dengesi ve döviz kurunun da açıklayıcı değişken olarak eklendiği bu çalışmanın sonucunda; altın fiyatlarının, İMKB100 Endeksi üzerinde doğrudan bir etkisinin olmadığı, ancak altının İKK100 endeksindeki değişimleri açıklayan parametreler arasında yer aldığı, dış ticaret dengesi dışındaki tüm değişkenlerin, İMKB100 endeksi üzerindeki etkilerinin döviz kurundan daha yüksek olduğu belirlenmiştir.

Elmas ve Esen (2011), Türkiye, Almanya, Rusya, Hindistan, Hollanda ve Fransa' da hisse senedi piyasaları ile döviz kuru arasındaki etkileşimleri, Engle-Granger eşbütünleşme testi ile incelemiş ve sadece Rusya'da bu değişkenler arasında eşbütünleşme ilişkisi belirleyebilmişlerdir. Yazarlar çalışmalarını Johansen eşbütünleşme testi ile genişlettiklerinde; iki ülkede (Rusya ve Türkiye'de) döviz kuru ile borsa arasında eşbütünleşme bulmuşlardır. Granger nedensellik testi uyguladıklarında ise dört ülkede (Türkiye, Almanya, Fransa ve Hollanda'da) dolar kurundan borsaya, iki ülkede (Rusya ve Hindistan'da) borsadan dolar kuruna doğru tek yönlü nedensellik ilişkileri tespit etmişlerdir.

Shahzadi ve Chohan (2012), altın fiyatlarındaki değişimlerin Pakistan Karachi Borsası üzerindeki etkilerini, Aralık 2006-31 Aralık 2010 dönemi için Johansen eşbütünleşme testi ve Granger nedensellik testi yardımıyla analiz etmiş ve bu değişkenler arasında negatif bir ilişkinin olduğunu belirlemişlerdir. Bu durumda, Pakistan'da altın ile hisse senetleri, birbirinin ikamesi durumundadır. Shaique vd. (2016) da 1993-2014 dönemi Karachi Borsa Endeksi ile altın fiyatları arasındaki ilişkileri Johansen eşbütünleşme testi ve VAR yöntemiyle analiz etmiş ve altının, bu ülkede hisse senetlerinin yakın bir ikamesi (alternatifi) olduğunu, altına yatırım yapacak kişilerin mutlaka bir önceki aydaki altın fiyatlarını da göz önünde bulundurmalarının yararlı olacağını, çünkü bu ülkedeki altın fiyatlarının, bir önceki aydaki altın fiyatlarından yüksek derecede etkilendiğini belirlemişlerdir. Benzer şekilde borsada yatırım yapacak kişi ve kurumların da son iki aydaki hisse senedi fiyatlarını göz önünde bulundurmalarının yararlı olacağını ifade etmişlerdir.

Bhunia ve Mukhuti (2013), altın fiyatlarının Hindistan'daki Bombay (Senex) ve Ulusal Borsa (Nifty) endeksleri üzerindeki etkilerini, 1991-2012 dönemi için Granger nedensellik testi ile incelemiş ve altın fiyatlarından Nifty'ye, Senex'ten altın fiyatlarına ve Senex'ten Nifty'e doğru tek yönlü nedensellik ilişkilerinin var olduğunu tespit etmiştir.

Akbaş (2013), İMKB100 endeksi getirisi ile faiz oranı arasındaki ilişkileri, 1986-2012 dönemi için Caner ve Hansen (2002) doğrusallık testi ve Hansen-Seo (2002) doğrusal olmayan eşbütünleşme testi ile incelemiş ve İMKB100 endeksi getirisi ile faiz oranı arasında uzun dönemli bir ilişki olduğunu belirlemiştir.

Özkan ve Kolay (2016), Türkiye'de altın fiyatlarına etki eden faktörleri, 1999-2014 dönemi için çoklu regresyon analiz yöntemiyle araştırmıştır. Yapılan analizler sonucunda; enflasyon ve faiz oranlarının altın fiyatlarını artırdığı tespit edilmiştir. Tursoy ve Faisal (2017), Türkiye'de ham petrol fiyatları ve altın fiyatlarının BIST100 üzerindeki etkilerini, 1986-2016 dönemi için FMOLS, DOLS ve CCR yöntemleriyle analiz etmiş ve altın ve hisse senetleri arasında negatif, petrol ve hisse senetleri arasında pozitif ilişkiler olduğunu tespit etmiştir. Bu durumda, Türkiye'de altın ile borsa birbirinin ikamesi durumundadır. 
Güney ve Saka Ilgın (2019), yatırım araçlarının BIST100 endeksi üzerindeki etkilerini, 2007-2018 dönemi için VAR yöntemiyle araştırmışlardır. Çalışmada, Johansen eşbütünleşme testi ve VAR analizinden yararlanan yazarlar, alternatif yatırım araçları olarak altın fiyatları, döviz kuru ve faiz oranı değişkenlerinden yararlanmışlardır. Yapılan analizler sonucunda, bu değişkenler arasında bir eşbütünleşme tespit edilmiş, Granger nedensellik testi sonucuna göre, altın ile BIST100 ve faiz ile BIST100 arasında karşılıklı, dövizden BIST100'e ve altından faize doğru tek yönlü nedensellik ilişkileri tespit edilmiştir. Etki-tepki fonksiyonları ve varyans ayrıştırması analizi sonuçlarına göre; BIST100'e alternatif yatırım araçları sıralamasının; faiz, döviz ve altın şeklinde olması gerektiği bulunmuştur.

Literatürdeki yer alan çalışmalara bakıldığında; borsa, faiz, döviz ve altının bir arada analize dâhil edildiği sınırlı sayıda çalışma olduğu görülmüştür. Yapılan bu çalışmada, bütün bu değişkenler bir arada kullanılarak, literatüre bir katkı sağlanması hedeflenmektedir.

\section{Ekonometrik Analiz}

\subsection{Veri Seti}

$\mathrm{Bu}$ çalışmada Türkiye'deki dört alternatif finansal yatırım aracı arasındaki dinamik etkileşimi analiz edebilmek için 2002:M01-2019:M11 dönemine ait aşağıda yer alan veriler kullanılmıştır.

Döviz: Çalışmada döviz kuru olarak, ABD Doları ve Euro'nun \%50 oranında ağırlıklandırılmasıyla oluşturulan kur sepeti verileri kullanılmıştır. Ayrıca ABD Doları ve Euro da kendi içinde alış ve satış fiyatlarının (kurlarının) aritmetik ortalaması alınarak kullanılmıştır. Bu veriler EVDS (2019a)'dan alınmıştır.

Faiz: Bankalarca açılan Türk Lirası mevduatlara uygulanan ağırlıklı ortalama faiz oranı verileri kullanılmıştır. Bu veriler EVDS (2019b)'den alınmıştır.

Altın: Serbest piyasada külçe altın gram ortalama satış fiyatı verileri kullanılmıştır. Bu veriler EVDS (2019c)'den alınmıştır.

Borsa: Borsa İstanbul (BIST100) Tüm Endeksi kapanış fiyatları verileri kullanılmıştır. Bu veriler EVDS (2019d)'den alınmıştır.

Faiz veriler baştan yıllık getiri (yıllık faiz oranı) olarak alınmış, diğer veriler de tarafımızdan bir önceki yılın aynı ayına göre yıllık getiriler şekline dönüştürülmüştür. Bir $X$ değişkeninin $t$ dönemindeki yıllık getirisini hesaplamayabilmek amacıyla kullanılan formül aşağıdaki gibidir:

Getiri $X_{t}=\left(\frac{X_{t}-X_{t-12}}{X_{t-12}}\right) * 100$

Böylece bütün seriler, yıllık yüzde getiri haline dönüştürülmüş ve analizlerde bu halleri kullanılmıştır. Bu verilerin zaman içindeki değişimleri Grafik 3 yardımıyla incelenebilir. 


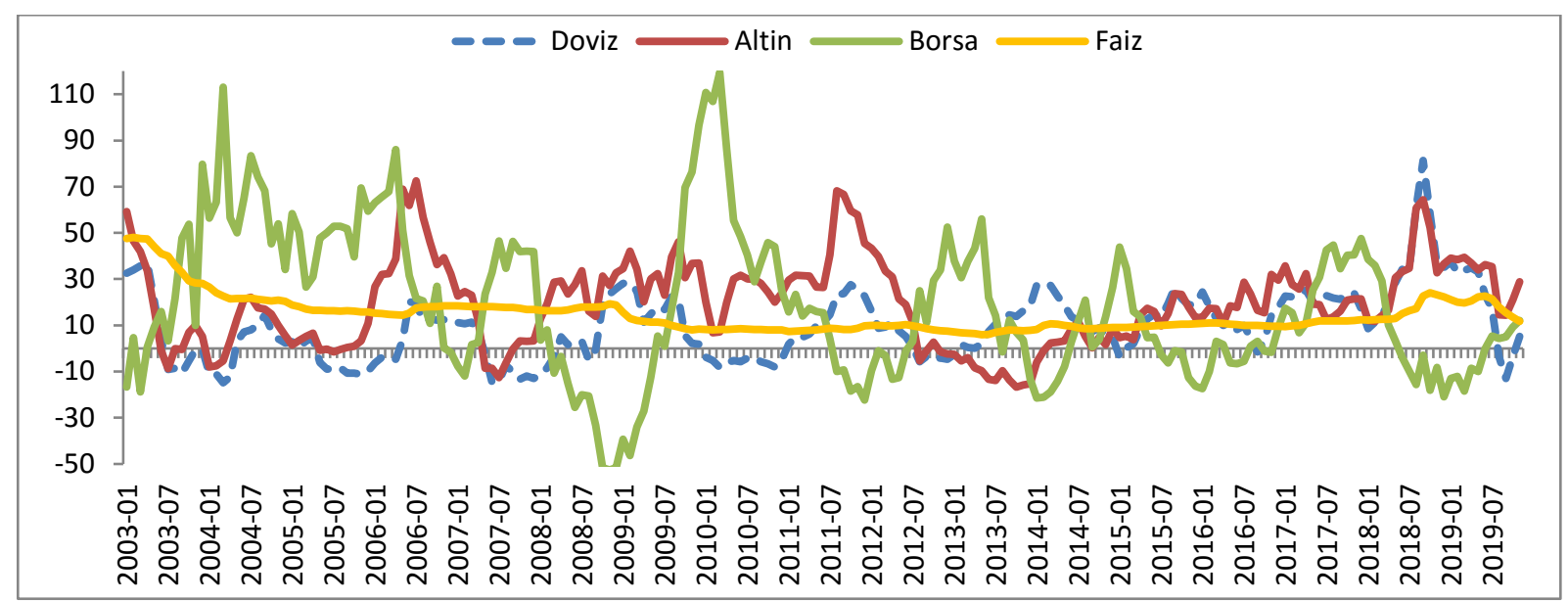

Grafik 3. Finansal Yatırım Araçlarının Yıllık Getirilerinin Zaman İçindeki Değişimi

Grafik 3'ten de görüldüğü üzere Türkiye'de getiri oynaklığı en yüksek olan yatırım aracı borsadır. Onu altın ve döviz takip etmektedir. Faiz ise en istikrarlı yatırım aracı konumundadır. Veri setine ait tanımlayıcı istatistikler Tablo 1'de yer almaktadır:

Tablo 1. Tanımlayıcı İstatistikler

\begin{tabular}{|l|c|c|c|c|}
\hline & Altın & Borsa & Döviz & Faiz \\
\hline Ortalama & 19.43966 & 18.33552 & 9.654122 & 14.6532 \\
\hline En Büyük & 72.49594 & 119.4401 & 81.33084 & 48.04 \\
\hline En Küçük & -16.7525 & -52.5675 & -14.8742 & 5.946 \\
\hline Standart Sapma & 18.60146 & 32.23663 & 15.0208 & 7.984678 \\
\hline Çarpıklık & 0.39208 & 0.56125 & 0.90571 & 2.120381 \\
\hline Basıklık & 2.971187 & 3.27059 & 5.087496 & 8.563817 \\
\hline Jarque-Bera & 5.208113 & 11.27687 & 64.61221 & 413.9519 \\
\hline Olasılık & 0.073973 & 0.003558 & 0.000 & 0.000 \\
\hline
\end{tabular}

Tablo 1'deki sonuçlara göre; serilerin standart sapmaları görece küçüktür. Bu durum, yapılacak analizler sonunda değişen varysans sorunu ile karşılaşılma olasılığını azaltmaktadır. Çalışmada 203 adet gözlem kullanılmış olup, bu durum; analizlerin serbestlik derecelerinin ve güvenilirliklerinin yüksek olduğunu ortaya koymaktadır. Veri setine ait korelasyon matrisi Tablo 2'de yer almaktadır:

Tablo 2. Korelasyon Matrisi

\begin{tabular}{|l|c|c|c|c|}
\hline & Altın & Borsa & Döviz & Faiz \\
\hline Altın & 1 & -0.29544 & 0.542167 & 0.097598 \\
\hline Borsa & -0.29544 & 1 & -0.56662 & -0.03913 \\
\hline Döviz & 0.542167 & -0.56662 & 1 & 0.119346 \\
\hline Faiz & 0.097598 & -0.03913 & 0.119346 & 1 \\
\hline
\end{tabular}

Korelasyon; iki serinin birlikte hareket etme eğiliminin bir ölçüsü olup, korelasyon katsayıları $(-1,1)$ aralığında değişen değerler alabilmektedirler. Korelasyon katsayısının 
土1'e yaklaşması, değişkenler arasındaki ilişkinin güçlü olduğunu göstermektedir. Korelasyon katsayısının işaretinin pozitif olması; değişkenlerin aynı yönlü hareket ettiklerini, negatif olması ise; değişkenlerin zıt yönlü hareket ettiklerini ifade etmektedir (Dursun, 2018). Bu bilgiler çerçevesinde Tablo 2'nin ilk sütununda yer alan bulgulara bakıldığında; altının getirisi ile borsanın getirisinin zıt yönlü ve bu değişkenlerin görece düşük bir ilişki içinde oldukları, altının getirisi ile döviz ve faiz getirilerinin aynı yönlü, dövizin getirisi ile olan ilişkinin daha güçlü olduğu görülmüştür. Yani kısaca altının; borsa ile ikame, döviz ve faiz ile tamamlayıcılık ilişkilerine sahip olduğu belirlenmiştir. Tablonun ikinci sütunundaki bilgilere göre; Borsa ile diğer tüm değişkenler arasında negatif (ikame) ilişki vardır. Tablo 2'nin üçüncü sütununa göre döviz; altın ve faiz ile tamamlayıcılık, borsa ile ikame ilişkisine sahiptir. Tablonun son sütununda yer alan bilgilere göre vadeli mevduatlardan elde edilen faiz getirisi; altın ve döviz ile tamamlayıcılık, borsa ile ikame ilişkisine sahiptir.

\subsection{Ekonometrik Modeller}

$\mathrm{Bu}$ çalışmada, alternatif yatırım araçlarının getirileri arasındaki dinamik etkileşimin incelenebilmesi için aşağıdaki ekonometrik modellerden yararlanılmıştır. Bu modellerin kurulmasında, literatürde yer alan Levin, Montagnoli ve Wright (2006); Elmas ve Esen (2011); Shahzadi ve Chohan (2012); Bhunia ve Mukhuti (2013); Akbaş (2013); Shaique, Aziz ve Herani (2016); Özkan ve Kolay (2016); Güney ve Saka Ilgın (2019) çalışmalarından yararlanılmıştır.

Model 1: Doviz $_{t}=\alpha_{0}+\alpha_{1}$ Altin $_{t}+\alpha_{2}$ Borsa $_{t}+\alpha_{3}$ Faiz $_{t}+e_{t}$

Model 2: Altin $_{t}=\beta_{0}+\beta_{1}$ Doviz $_{t}+\beta_{2}$ Borsa $_{t}+\beta_{3}$ Faiz $_{t}+\varepsilon_{t}$

Model 3: Borsa $_{t}=\gamma_{0}+\gamma_{1}$ Altin $_{t}+\gamma_{2}$ Doviz $_{t}+\gamma_{3}$ Faiz $_{t}+\epsilon_{t}$

Model 4: Faiz $_{t}=\theta_{0}+\theta_{1}$ Altin $_{t}+\theta_{2}$ Borsa $_{t}+\theta_{3}$ Doviz $_{t}+\omega_{t}$

Burada $t$; zamanı, $e_{t}, \varepsilon_{t}, \epsilon_{t}$ ve $\omega_{t}$ ise stokastik hata terimleri serilerini göstermektedir. $\mathrm{Bu}$ modellerde tüm değişkenler sırasıyla bağımlı değişken yapılarak, tüm değişkenlerin birbiri üzerindeki etkileri eşanlı olarak analiz edilmeye çalışılmıştır. Yapılacak analizler sonucunda; bir değişkenin katsayısının negatif çıkması; o değişken ile o modelde yer alan bağımlı değişken arasında ikame ilişkisinin (alternatif yatırım aracı olma durumunun) varlığını gösterecektir. Yani bu değişkenlerden birinin getirisi artarken, diğerinin (bağımlı değişken durumunda olan değişkenin) getirisi azalmıştır. Yatırımcıların portföylerini oluştururken, bu şekildeki yatırım araçlarından sadece birini portföylerine dâhil etmeleri daha rasyonel bir karar olacaktır. Bağımsız değişkenin katsayısının pozitif olması ise; bu değişken ile bağımlı değişken arasında tamamlayıcılık ilişkisinin olduğunu ifade edecektir. Bu şekildeki yatırım araçlarının portföyde birlikte tutulmasında yarar olduğuna karar verilecektir.

\subsection{Yöntem}

$\mathrm{Bu}$ çalışmada serilerin durağanlıkları Dickey ve Fuller $(1979,1981)$ tarafindan geliştirilen ADF (Augmented Dickey Fuller: Geniş̧letilmiş Dickey Fuller) ve Phillips ve Perron (1988) tarafından geliştirilen PP birim kök testleri ile analiz edilmiştir. Değişkenler arasındaki eşanlı etkileşim VAR modeli ve bu modele dalalı olarak elde edilen Etki-Tepki Fonksiyonları ve 
yine VAR modeline adayalı olarak gerçekleştirilen Varyans Analizi yöntemleriyle incelenmiştir. Seriler arasındaki nedensellik ilişkileri de Granger (1969) yöntemiyle test edilmiştir.

\subsection{Birim Kök Testleri}

Birim kök testleri; serilerin durağanlık seviyelerinin belirlenmesine olanak sağlamaktadır. $\mathrm{Bu}$ çalışmada serilerin durağanlıkları ADF ve PP birim kök testleriyle incelenmiştir. Bu testlerin $H_{0}$ hipotezleri; "Seri durağan değildir" şeklindedir. ADF ve PP birim kök testlerinden elde edilen sonuçlar Tablo 3'te sunulmuştur:

Tablo 3. Birim Kök Testi Sonuçları

\begin{tabular}{|c|c|c|c|c|}
\hline & \multicolumn{2}{|c|}{$A D F$} & \multicolumn{2}{|c|}{$P P$} \\
\hline & Test İstatistiği & Olasılık & Test Istatistiği & Olasılık \\
\hline Altın & -2.42 & 0.36 & $-3.95 * *$ & 0.01 \\
\hline Borsa & $-3.21^{*}$ & 0.08 & $-4.02 * * *$ & 0.00 \\
\hline Döviz & $-3.81 * *$ & 0.01 & $-3.85 * *$ & 0.01 \\
\hline Faiz & $-3.89 * *$ & 0.01 & $-4.02 * * *$ & 0.00 \\
\hline
\end{tabular}

Not: ADF Testinde optimum gecikme uzunluğu Akaike (1974) bilgi kriterine göre, PP testinde optimum band genişliği Newey-West (1994) yöntemiyle belirlenmiştir. *, ** ve *** sirasıyla $\% 10, \% 5$ ve $\% 1$ anlamlılık düzeyinde $H_{0}$ hipotezinin reddedildiğini ve ilgili serinin durağan olduğunu göstermektedir.

Tablo 3'teki analizlere göre bütün seriler düzey değerlerinde durağan, yani I(0)'dır. Bu durumda Granger ve Newbold (1974)'e göre bu serilerin düzey değerleri kullanılarak yapılacak analizlerde sahte regresyon problemi ile karşılaşılmayacaktır.

\subsection{VAR Analizi}

Sims (1980) tarafından geliştirilen VAR (Vector Autoregressive) analizleri, değişkenler arasındaki ilişkileri eşanlı incelemeye imkân sağlamaktadır. Özellikle serilerin düzey değerlerinde durağan olduklarında etkin sonuçlar veren VAR (Sims, 2013: 12) analizini bu çalışmada uygulayabilmek için kullanılan denklem sistemi:

$$
\begin{aligned}
& \text { Doviz }_{t}=\alpha_{0}+\sum_{k=1}^{m} \alpha_{1 k} \text { Doviz }_{t-k}+\sum_{k=1}^{m} \alpha_{2 k} \text { Altin }_{t-k}+\sum_{k=1}^{m} \alpha_{3 k} \text { Borsa }_{t-k}+\sum_{k=1}^{m} \beta_{4 k} \text { Faiz }_{t-k}+e_{t} \\
& \text { Altin }_{t}=\beta_{0}+\sum_{k=1}^{m} \beta_{1 k} \text { Altin }_{t-k}+\sum_{k=1}^{m} \beta_{2 k} \text { Doviz }_{t-k}+\sum_{k=1}^{m} \beta_{3 k} \text { Borsa }_{t-k}+\sum_{k=1}^{m} \beta_{4 k} \text { Faiz }_{t-k}+\varepsilon_{t} \\
& \text { Borsa }_{t}=\gamma_{0}+\sum_{k=1}^{m} \gamma_{1 k} \text { Borsa }_{t-k}+\sum_{k=1}^{m} \gamma_{2 k} \text { Altin }_{t-k}+\sum_{k=1}^{m} \gamma_{3 k} \text { Doviz }_{t-k}+\sum_{k=1}^{m} \gamma_{4 k} \text { Faiz }_{t-k}+\epsilon_{t} \\
& \text { Faiz }_{t}=\theta_{0}+\sum_{k=1}^{m} \theta_{1 k} \text { Faiz }_{t-k}+\sum_{k=1}^{m} \theta_{2 k} \text { Altin }_{t-k}+\sum_{k=1}^{m} \theta_{3 k} \text { Borsa }_{t-k}+\sum_{k=1}^{m} \theta_{4 k} \text { Doviz }_{t-k}+\omega_{t}
\end{aligned}
$$

Bu modellerde yer alan m; Akaike (1974), Schwarz (1978), Hannan ve Quin (1979) gibi bilgi kriterleri yardımıyla belirlenecek optimum gecikme uzunluğunu göstermektedir. Bu denklemleri kapalı formda yazmak gerekirse; 
$Z_{t}=\Gamma_{0}+\Gamma_{1} Z_{t-1}+u_{t}$

olur.

Burada;

$Z_{i t}=\left[\begin{array}{c}\text { Doviz }_{t} \\ \text { Altin }_{t} \\ \text { Borsa }_{t} \\ \text { Faiz }_{t}\end{array}\right], \Gamma_{0}=\left[\begin{array}{c}\alpha_{0} \\ \beta_{0} \\ \gamma_{0} \\ \theta_{0}\end{array}\right], \Gamma_{1}=\left[\begin{array}{cccc}\alpha_{1} & \alpha_{2} & \alpha_{3} & \alpha_{4} \\ \beta_{1} & \beta_{2} & \beta_{3} & \beta_{4} \\ \gamma_{1} & \gamma_{2} & \gamma_{3} & \gamma_{4} \\ \theta_{1} & \theta_{2} & \theta_{3} & \theta_{4}\end{array}\right], Z_{t-1}=\left[\begin{array}{c}\text { Doviz }_{t-1} \\ \text { Altin }_{t-1} \\ \text { Borsa }_{t-1} \\ \text { Faiz }_{t-1}\end{array}\right]$ ve $u_{t}=\left[\begin{array}{c}e_{t} \\ \varepsilon_{t} \\ \epsilon_{t} \\ \omega_{t}\end{array}\right]$

biçiminde tanımlanabilir.

VAR analizlerinde elde edilen bulguları (katsayıları) direk yorumlamak yerine, elde edilen VAR bulgularına dayanılarak türetilecek Etki - Tepti Fonksiyonları ve yine ulaşılan VAR bulgularına dayanılarak gerçekleştirilecek Varyans Ayrıştırması sonuçları yorumlanmaktadır. $\mathrm{Bu}$ analizlerden Etki - Tepki Fonksiyonları; sistemde yer alan değişkenlerden biri üzerine gelen bir standart sapmalık şoka, diğer değişkenlerin verdikleri tepkileri ortaya koyarken, Varyans Ayrıştırması analizi; bir değişkende meydana gelen değişimlerin yüzde kaçının kendisinden, yüzde kaçının diğer değişkenlerden kaynaklandığını belirlemeye imkân tanımaktadır (Zivot, 2011).

VAR analizlerinde öncelikle optimum gecikme uzunluğunun belirlenmesi gerekmektedir. $\mathrm{Bu}$ çalışmada yapılan optimum gecikme uzunluğu bulma işlemi sonuçları Tablo 4'te yer almaktadir.

Tablo 4. Optimum Gecikme Uzunluğu Bulma İșlemi Sonuçları

\begin{tabular}{|c|c|c|c|c|c|}
\hline Lag & LR & FPE & AIC & SC & HQ \\
\hline 0 & NA & $1.13 \mathrm{e}+09$ & 32.19601 & 32.26314 & 32.22319 \\
\hline 1 & 1734.856 & 144037.0 & 23.22929 & 23.56498 & 23.36521 \\
\hline 2 & 150.7447 & $75485.11^{*}$ & $22.58294 *$ & $23.18718^{*}$ & $22.82759 *$ \\
\hline 3 & 22.36774 & 78701.96 & 22.62414 & 23.49694 & 22.97753 \\
\hline
\end{tabular}

Tablo 4'teki bulgulara göre FPE, AIC, SC ve HQ bilgi kriterlerine göre optimum gecikme uzunluğu 2'dir. 2 gecikmeli VAR modeli (VAR(2)) tahmin edilmiş ve bu modelin istikrarlı olup olmadığını görebilmek için ters karakteristik kökler grafiği çizilmiştir. Bu grafikte ters köklerin birim çemberin içinde kaldığ 1 için görüldüğü için VAR(2) modeli ve bu model esas alınarak gerçekleştirilecek analizlerin istikrarlı olduğuna karar verilmiştir. VAR(2) modelinde otokorelasyon sorunun varlığı test edilmiş ve elde edilen sonuçlar Tablo 5'te sunulmuştur.

Tablo 5. Otokorelasyon Testi Sonuçları

\begin{tabular}{|c|c|c||c|c|}
\hline & \multicolumn{2}{|c|}{ LRE $^{\#}$} & \multicolumn{2}{c|}{ Rao } \\
\hline Lag & Test İstatistiği & Olasılık Değeri & F-İstatistiği & Olasılık Değeri \\
\hline 1 & $22.08^{* * *}$ & 0.14 & $1.39 * * *$ & 0.14 \\
\hline 2 & $40.04 * * *$ & 0.15 & $1.26^{* * *}$ & 0.15 \\
\hline
\end{tabular}

Not: \#; Edgeworth genişlemesi düzeltilmiş olabilirlik oranı istatistiğini ifade etmektedir. ***; \%1 anlamlılık düzeyinde modelde otokorelasyon sorununun olmadığını göstermektedir. 
Tablo 5'teki bulgulara göre; $\operatorname{VAR}(2)$ modelinde otokorelasyon sorunu yoktur. $\mathrm{Bu}$ modelde değişen varyans sorununun varlığ da test edilmiş ve elde edilen bulgular Tablo 6'da sunulmuştur.

Tablo 6. Değişen Varyans Testi Sonuçları

\begin{tabular}{|c|c|c|}
\hline Ki-Kare Test İstatistiği & Serbestlik Derecesi & Olasılık Değeri \\
\hline 376.94 & $160^{* * *}$ & 0.45 \\
\hline
\end{tabular}

Not: ***; \%1 anlamlılık düzeyinde modelde değişen varyans sorununun olmadığını göstermektedir.

Tablo 6'daki bulgulara göre; VAR(2) modelinde değișen varyans sorunu yoktur. Dolayısıyla VAR(2) modeline dayanarak gerçekleştirilecek Etki-Tepti Fonksiyonları ve Varyans Ayrıştırma analizleri güvenilir olacaktır.

\subsection{Etki - Tepki Fonksiyonları}

Finansal varlıklardan birinde meydana gelen bir değişimin diğerleri üzerindeki etkilerini ortaya çıkarabilmek için Etki - Tepki Fonksiyonları üretilmiş ve elde edilen sonuçlar Grafik 4'te sunulmuştur.

ne S.D. Innovations \pm 2 S.E.

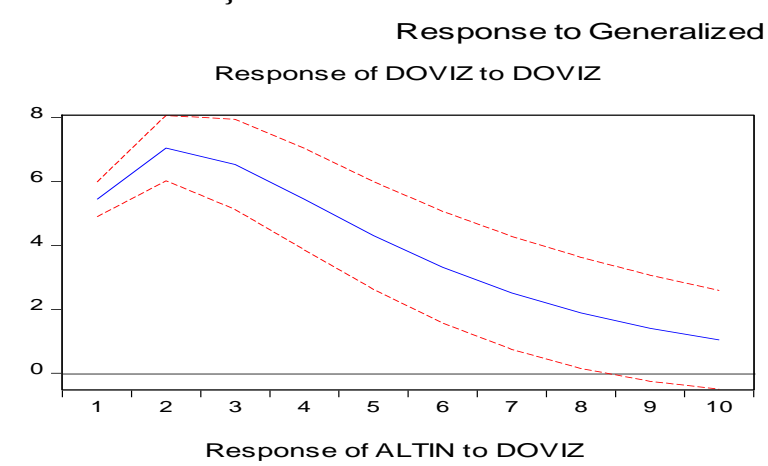

Response of DOVIZ to DOVIZ

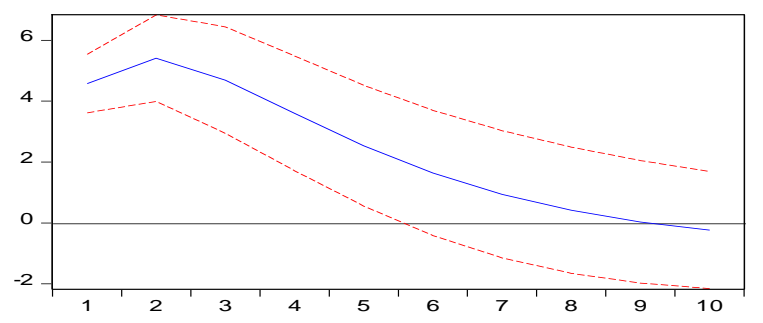

Response of BORSA to DOVIZ

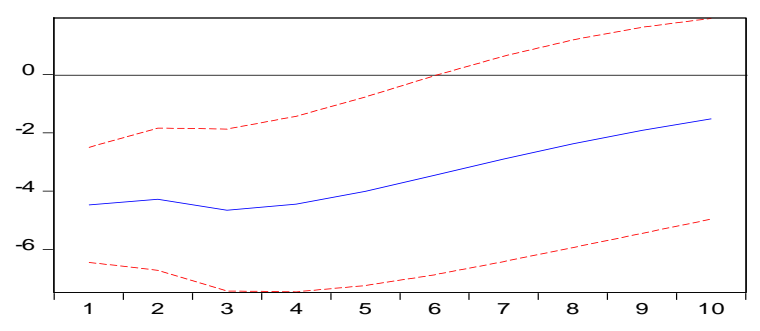

Response of FAIZ to DOVIZ

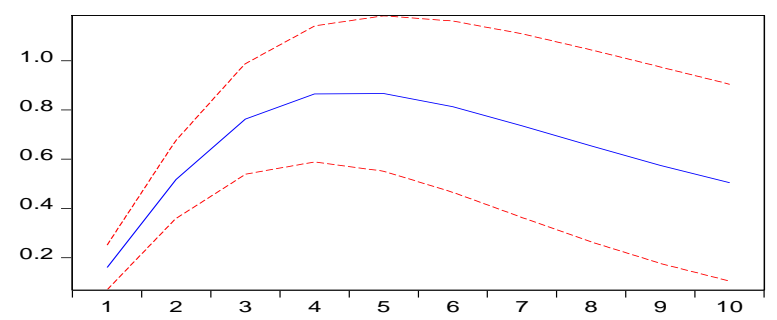

Grafik 4. Dövizin Getirisinde Meydana Gelen Bir Artışa Diğer Finansal Değişkenlerin Verdikleri Tepkiler

Grafik 4'teki bulgulara göre; dövizin getirisinde meydana gelen bir artış şokuna karşılık; borsa, altın ve faiz ilk dönemde artış yönünde tepki vermiş, daha sonra altın ve faiz azalmaya geçmiştir. Bu durumda yatırımcıların; dövizdeki artışı takip eden dönemde altın ve vadeli mevduattan döviz alımına doğru bir hareketlenme olabileceği göz önünde bulundurmalarında yarar vardır. Altının getirisinde meydana gelen bir artış şoku karşısında diğer finansal araçların verdikleri tepkiler Grafik 5'te yer almaktadır. 
Response to Generalized One S.D. Innovations \pm 2 S.E.

Response of ALTIN to ALTIN

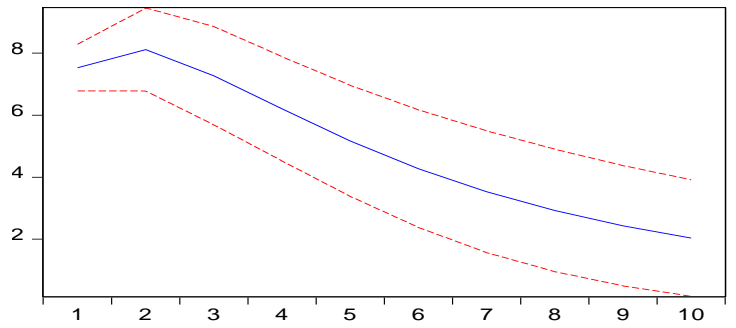

Response of DOVIZ to ALTIN

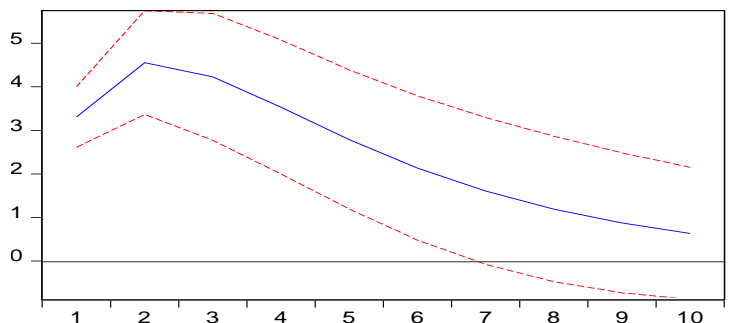

Response of BORSA to ALTIN

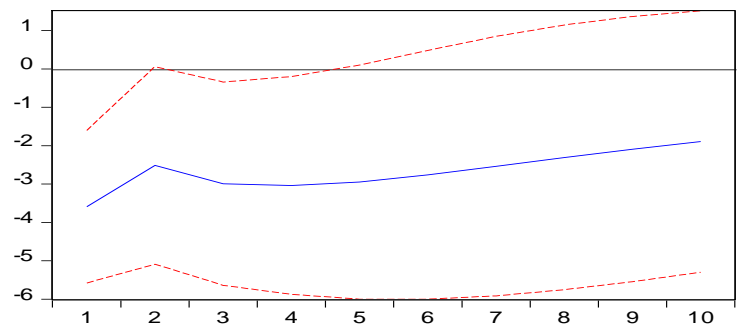

Response of FAIZ to ALTIN

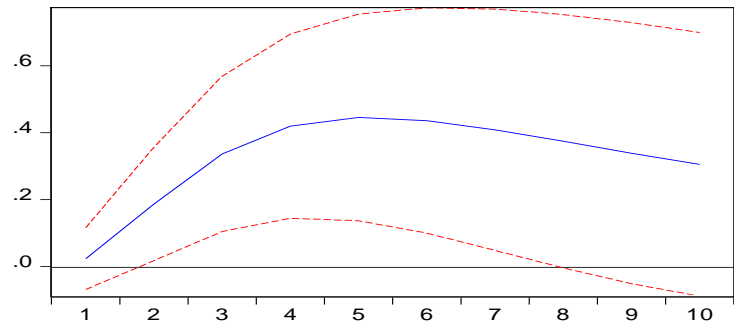

Grafik 5. Altının Getirisinde Meydana Gelen Bir Artışa Diğer Finansal Değişkenlerin Verdikleri Tepkiler

Grafik 5'teki bulgulara göre; altının getirisinde meydana gelen bir artış şokuna karşıllı; borsa, altın ve faiz ilk dönemde artış yönünde tepki vermiş, daha sonra döviz ve altının getirisi azalmaya başlamıştır. Bu durumda yatırımcıların; altın fiyatlarındaki artışı takip eden dönemde döviz ve vadeli mevduattan çıkıp, altın alımına yönelebileceklerini göz önünde bulundurmalarında yarar vardır. Borsanın getirisinde meydana gelen bir artış şoku karşısında diğer finansal araçların verdikleri tepkiler Grafik 6'da yer almaktadır.

Response to Generalized One S.D. Innovations \pm 2 S.E.

Response of BORSA to BORSA

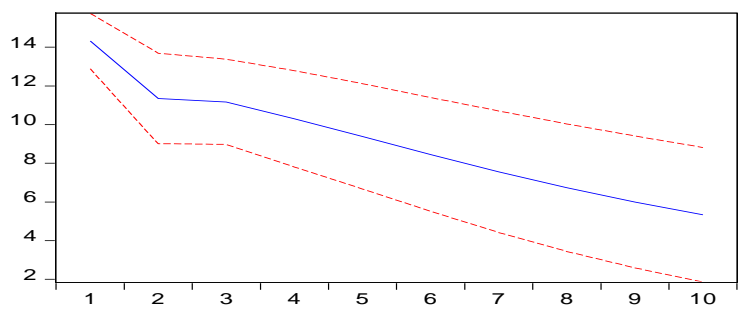

Response of DOVIZ to BORSA

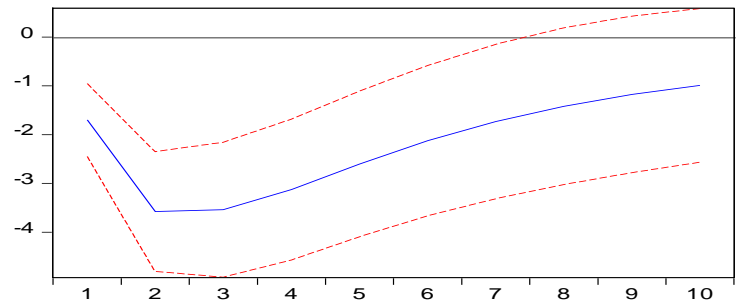

Response of ALTIN to BORSA

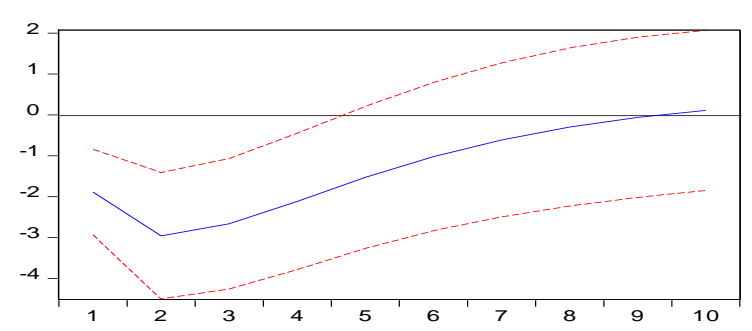

Response of FAIZ to BORSA

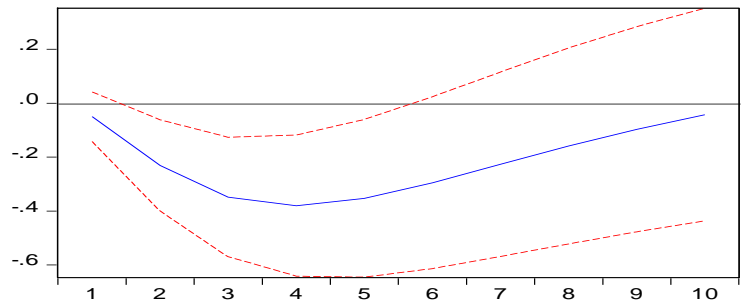

Grafik 6. Borsanın Getirisinde Meydana Gelen Bir Artışa Diğer Finansal Değişkenlerin Verdikleri Tepkiler

Grafik 6'daki bulgulara göre; borsanın getirisinde meydana gelen bir azalış şokuna karşılık; altın, döviz ve faiz ilk dönemde artış yönünde tepki vermiş, daha sonra her üçünün de getirisi artmaya başlamıştır. Bu durumda; Türkiye'deki finansal piyasaların ilk etapta genel 
ekonomik konjonktüre göre (birlikte) hareket ettiği, daha sonra yatırımcıların, düşen finansal yatırım aracının ikamesi (alternatifi) olan yatırım araçlarına yöneldikleri söylenebilir. Yatırımcıların da bu gerçeği göz önünde bulundurarak, yatırım sepetlerini çeşitlendirmelerinde yarar vardır. Vadeli mevduatların getirilerinde (faizde) getirisinde meydana gelen bir artış şoku karşısında diğer finansal araçların verdikleri tepkiler Grafik 7'de yer almaktadır.

Response to Generalized One S.D. Innovations \pm 2 S.E.

Response of FAIZ to FAIZ

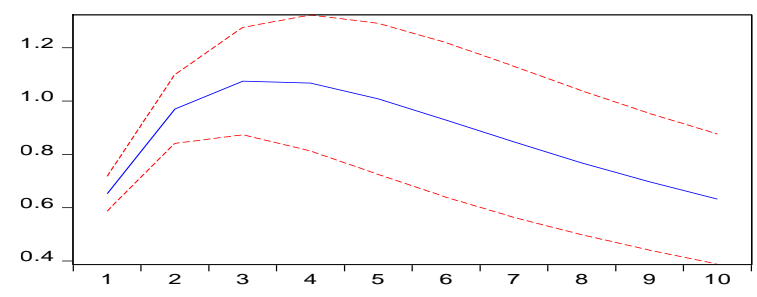

Response of ALTIN to FAIZ

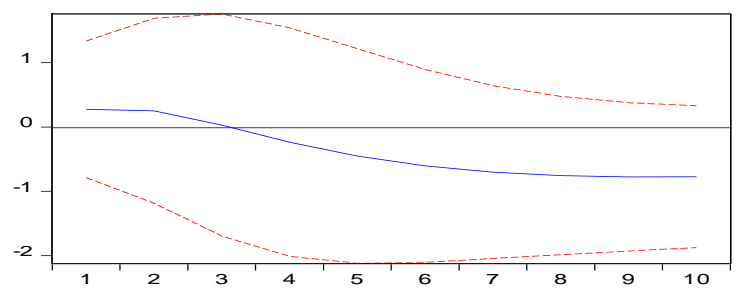

Response of BORSA to FAIZ

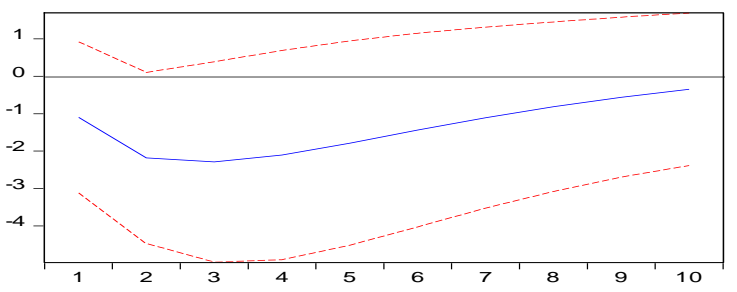

Response of DOVIZ to FAIZ

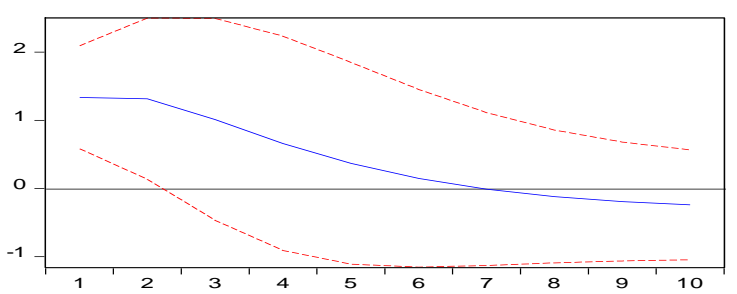

Grafik 7. Faiz Getirisinde Meydana Gelen Bir Artışa Diğer Finansal Değişkenlerin Verdikleri Tepkiler

Grafik 7'deki bulgulara göre; vadeli mevduatların getirisinde (faizde) meydana gelen bir artış şokuna karşılık; borsa, altın ve döviz azalma yönünde tepki vermiştir. Demek ki borsa, altın ve döviz, Türkiye'de vadeli mevduatların açık bir ikamesidir. Yatırımcıların bu bilinçle hareket etmelerinde yarar vardır.

\subsection{Varyans Ayrıștırması Analizi}

Çalışmada, her bir finansal yatırım aracında meydana gelen değişimlerin ne kadarının kendinden, ne kadarının diğer yatırım araçlarından kaynaklandığını eşanlı olarak analiz edebilmek için Varyans Ayrıştırması Analizleri de yapılmış ve ilk sonuçlar Tablo 7'de sunulmuştur.

Tablo 7. Faiz Getirisinde Meydana Gelen Değişimlere Yönelik Varyans Ayrıştırma Sonuçları

\begin{tabular}{|c|c|c|c|c|}
\hline DÖNEM & FAIZ & DOVIZ & ALTIN & BORSA \\
\hline 1 & 91.92801 & 7.450716 & 0.132894 & 0.488381 \\
\hline$\cdots$ & $\cdots$ & $\cdots$ & $\cdots$ & $\cdots$ \\
\hline 6 & 55.10955 & 30.71327 & 10.05417 & 4.123010 \\
\hline $\mathbf{7}$ & $\mathbf{5 4 . 0 2 2 6 7}$ & $\mathbf{3 1 . 3 1 4 6 2}$ & $\mathbf{1 0 . 8 5 3 3 3}$ & $\mathbf{3 . 8 0 9 3 8 2}$ \\
\hline 8 & 53.46254 & 31.61480 & 11.41566 & 3.507002 \\
\hline
\end{tabular}


Tablo 7'de değişimler 7. periyottan sonra dengeye geldiği için bu periyottaki bulgular yorumlanmıştır. Buna göre; vadeli mevduatlardan elde edilen faiz getirisindeki değişimlerin \%54'ü kendinde meydana gelen değişimlerden, \%31'i dövizin getirisinde meydana gelen değişimlerden, \%10.8'i altının getirisindeki değişimlerden ve \%3.8'i borsanın getirisinde meydana gelen değişimlerden kaynaklanmıştır. Bu durumda vadeli mevduatın en önemli ikamesi dövizdir. Yatırımcıların da portföylerini oluştururken, faizden sonra en büyük payı dövize ayırmaları rasyonel bir davranış olacaktır. Altının getirisinde meydana gelen değişimlere yönelik varyans ayrıştırma sonuçları Tablo 8'de yer almaktadır.

Tablo 8. Altının Getirisinde Meydana Gelen Değişimlere Yönelik Varyans Ayrıştırma Sonuçları

\begin{tabular}{|c|c|c|c|c|}
\hline DÖNEM & ALTIN & BORSA & DÖVİ & FAIZ \\
\hline 1 & 100.0000 & 0.000000 & 0.000000 & 0.000000 \\
\hline$\ldots$ & $\ldots$ & $\ldots$ & $\ldots$ & $\ldots$ \\
\hline 22 & 87.15078 & 2.258401 & 10.05664 & 0.534178 \\
\hline $\mathbf{2 3}$ & $\mathbf{8 6 . 9 6 2 8 6}$ & $\mathbf{2 . 3 0 9 3 5 6}$ & $\mathbf{1 0 . 1 9 2 2 5}$ & $\mathbf{0 . 5 3 5 5 3 5}$ \\
\hline 24 & 86.80557 & 2.353761 & 10.30408 & 0.536584 \\
\hline
\end{tabular}

Tablo 8'deki bulgulara göre altının getirisi 23. dönemden sonra dengeye gelmiştir. Bu durum; altının uzun vadeli bir yatırım aracı olduğunu ve ortalama 23 ayda maksimum getirisine ulaştığını göstermektedir. Altının getirisinde meydana gelen değişimlerin \%86.9'u kendisinden, \%10.2'si dövizden, \%2.3'ü borsada meydana gelen değişimlerden kaynaklanmıştır. Bu sonuçlar iki şeyi ortaya koymaktadır: Birincisi; altın fiyatlarının yurtiçi dinamiklerden çok, uluslararası dinamiklere göre şekillendiğini, ikincisi ise; uluslararası piyasalarda altın fiyatları dolar cinsinden belirlendiği ve işlem gördüğü için, dövizde meydana gelen değişimlerin altının yurtiçi satış fiyatlarını önemli ölçüde etkilendiğidir. Dolayısıyla finansal yatırımcıların da bu hususlara dikkat etmelerinde yarar vardır. Borsanın getirisinde meydana gelen değişimlere yönelik varyans ayrıştırma sonuçları Tablo 9'da yer almaktadır.

Tablo 9. Borsanın Getirisinde Meydana Gelen Değişimlere Yönelik Varyans Ayrıştırma Sonuçları

\begin{tabular}{|c|c|c|c|c|}
\hline DÖNEM & BORSA & ALTIN & DÖVIZ & FAIZ \\
\hline 1 & 93.72182 & 6.278179 & 0.000000 & 0.000000 \\
\hline$\cdots$ & $\cdots$ & $\cdots$ & $\cdots$ & $\cdots$ \\
\hline 7 & 91.07222 & 7.573028 & 0.770573 & 0.584184 \\
\hline $\mathbf{8}$ & $\mathbf{9 0 . 9 1 2 9 5}$ & $\mathbf{7 . 7 9 2 4 9 6}$ & $\mathbf{0 . 7 2 9 6 5 1}$ & $\mathbf{0 . 5 6 4 9 0 4}$ \\
\hline 9 & 90.77213 & 7.966696 & 0.715205 & 0.545968 \\
\hline
\end{tabular}

Tablo 9'da borsanın getirisinde yaşanan değişimler 8. periyottan sonra dengeye geldiği için bu periyottaki bulgular yorumlanmıştır. Buna göre; borsada yaşanan değişimlerin \%90.9'u kendinde meydana gelen değişimlerden ve \%7.8'i altının getirisindeki değişimlerden kaynaklanmıştır. Bu durumda borsanın getirisinin en önemli ikamesi dövizdir. Yatırımcıların da portföylerini oluştururken, borsadan sonra en büyük payı dövize ayırmaları rasyonel bir 
davranış olacaktır. Dövizlerin getirisinde meydana gelen değişimlere yönelik varyans ayrıştırma sonuçları Tablo 10’da yer almaktadır.

Tablo 10. Dövizin Getirisinde Meydana Gelen Değişimlere Yönelik Varyans Ayrıştırma Sonuçları

\begin{tabular}{|c|c|c|c|c|}
\hline DÖNEM & DÖVIZ & ALTIN & BORSA & FAIZ \\
\hline 1 & 60.34859 & 36.91156 & 2.73985 & 0.00000 \\
\hline$\cdots$ & $\cdots$ & $\cdots$ & $\cdots$ & $\cdots$ \\
\hline 7 & 46.81078 & 38.29648 & 13.71678 & 1.17595 \\
\hline $\mathbf{8}$ & $\mathbf{4 6 . 5 0 1 6 7}$ & $\mathbf{3 8 . 1 1 2 6 5}$ & $\mathbf{1 4 . 0 5 5 6 4}$ & $\mathbf{1 . 3 3 0 0 5}$ \\
\hline 9 & 46.25632 & 37.94785 & 14.32971 & 1.46612 \\
\hline
\end{tabular}

Tablo 10'da dövizin getirisinde yaşanan değişimler 8. periyottan sonra dengeye geldiği için bu periyottaki bulgular yorumlanmıştır. Buna göre; dövizin getirisinde yaşanan değişimlerin \%46.5'i kendinde meydana gelen değişimlerden, \%38'i altında meydana gelen değişimlerden, \%14'ü borsada meydana gelen değişimlerden ve \%1.3'ü faizde meydana gelen değişimlerden kaynaklanmıştır. Bu durumda dövizin getirisinin en önemli ikamesi altındır. Yatırımcıların da portföylerini oluştururken, dövizden sonra en büyük payı altına ayırmaları mantıklı bir karar olacaktır.

\subsection{Granger Nedensellik Testi}

Granger (1969) testi, düzey değerlerinde durağan seriler arasındaki nedensellik ilişkilerinin tespit edilmesinde etkin bir yöntemdir. $\mathrm{Bu}$ testte de aşağıdaki denklem sisteminden yararlanılmıştır:

$$
\begin{aligned}
& \text { Doviz }_{t}=\alpha_{0}+\sum_{k=1}^{m} \alpha_{1 k} \text { Doviz }_{t-k}+\sum_{k=1}^{m} \alpha_{2 k} \text { Altin }_{t-k}+\sum_{k=1}^{m} \alpha_{3 k} \text { Borsa }_{t-k}+\sum_{k=1}^{m} \beta_{4 k} \text { Faiz }_{t-k}+e_{t} \\
& \text { Altin }_{t}=\beta_{0}+\sum_{k=1}^{m} \beta_{1 k} \text { Altin }_{t-k}+\sum_{k=1}^{m} \beta_{2 k} \text { Doviz }_{t-k}+\sum_{k=1}^{m} \beta_{3 k} \text { Borsa }_{t-k}+\sum_{k=1}^{m} \beta_{4 k} \text { Faiz }_{t-k}+\varepsilon_{t} \\
& \text { Borsa }_{t}=\gamma_{0}+\sum_{k=1}^{m} \gamma_{1 k} \text { Borsa }_{t-k}+\sum_{k=1}^{m} \gamma_{2 k} \text { Altin }_{t-k}+\sum_{k=1}^{m} \gamma_{3 k} \text { Doviz }_{t-k}+\sum_{k=1}^{m} \gamma_{4 k} \text { Faiz }_{t-k}+\epsilon_{t} \\
& \text { Faiz }_{t}=\theta_{0}+\sum_{k=1}^{m} \theta_{1 k} \text { Faiz }_{t-k}+\sum_{k=1}^{m} \theta_{2 k} \text { Altin }_{t-k}+\sum_{k=1}^{m} \theta_{3 k} \text { Borsa }_{t-k}+\sum_{k=1}^{m} \theta_{4 k} \text { Doviz }_{t-k}+\omega_{t}
\end{aligned}
$$

Denklem (13)'te Altın'dan Döviz'e doğru nedenselliğin varlığı konusunda sınan hipotezler;

$$
\begin{array}{ll}
H_{0}: \alpha_{2 k}=0 & \text { Altından Dövize doğru nedensellik ilişkisi yoktur } \\
H_{1}: \alpha_{2 k} \neq 0 & \text { Altından Dövize doğru nedensellik ilişkisi vardır }
\end{array}
$$

şeklindedir. Benzer hipotezler Borsa ve Faizden Dövize doğru olan nedensellik ilişkilerinin sınanması için de kurulmaktadır. Denklem (14), Denklem (15) ve Denklem (16)'da ise sırasıyla altın, borsa ve faize doğru olan nedensellik ilişkileri incelenmektedir. Yukarıdaki modellerde yer alan optimum gecikme uzunluğu $(m)$ olarak, Tablo 4'te belirlenen gecikme uzunluğu (2) kullanılmıştır. Böylece 2 gecikme ile Granger (1969) nedensellik testi yapılmış ve elde edilen sonuçlar Tablo 11'de sunulmuştur. 
Tablo 11. Granger Nedensellik Testi Sonuçları

\begin{tabular}{|l|c|c|}
\hline Nedensellik İlișkisinin Yönü & $\boldsymbol{F}$ İstatistĭgi & Olasillk \\
\hline BORSA $\mapsto$ ALTIN & 1.99420 & 0.1389 \\
\hline ALTIN $\mapsto$ BORSA & 0.32210 & 0.7250 \\
\hline \hline DOVIZ $\mapsto$ ALTIN & $2.54894^{*}$ & 0.0808 \\
\hline ALTIN $\mapsto$ DOVIZ & 0.64708 & 0.5247 \\
\hline \hline FAIZ $\mapsto$ ALTIN & 1.16391 & 0.3144 \\
\hline ALTIN $\mapsto$ FAIZ & $5.77950^{* * *}$ & 0.0036 \\
\hline \hline DOVIZ $\mapsto$ BORSA & 0.79274 & 0.4540 \\
\hline BORSA $\mapsto$ DOVIZ & $7.63068^{* * *}$ & 0.0006 \\
\hline \hline FAIZ $\mapsto$ BORSA & 2.07910 & 0.1278 \\
\hline BORSA $\mapsto$ FAIZ & $4.76000^{* * *}$ & 0.0096 \\
\hline \hline FAIZ $\mapsto$ DOVIZ & 2.28001 & 0.1050 \\
\hline DOVIZ $\mapsto$ FAIZ & $18.9252^{* * *}$ & 0.0003 \\
\hline
\end{tabular}

Not: * ve ***; okun solundaki değişkenden, sırasıyla $\% 10$ ve $\% 1$ anlamlılık düzeyinde $H_{0}$ hipotezinin reddedildiğini ve okun solundaki değişkenden okun sağındaki değişkene doğru bir nedensellik ilişkisinin var olduğunu göstermektedir.

Tablo 11'deki bulgulara göre; dövizden altına, altın, borsa ve dövizden faize ve borsadan dövize doğru tek yönlü nedensellik ilişkileri vardır. O halde Türkiye’de bu finansal enstrümanlar birbirini etkilemektedirler. Yatırımcıların ve politika yapıcıların kararlarını, değişkenler arasındaki bu dinamik etkileşimleri göz önünde bulundurarak almalarında yarar vardir.

\section{Sonuç ve Politika Önerileri}

Yurtiçi tasarruf oranlarının artırılması; yurtiçi yatırım ve tüketim faaliyetlerinin dış borç yaratmadan finanse edilebilmesi ve böylece, bir yandan ülkenin ekonomik büyümesi hızlandırılırken, diğer yandan da ülkenin iç ve dış finansal şoklar karşısındaki dayanıklılığının artırılabilmesi bağlamında büyük önem taşımaktadır. Aksi takdirde cari açık sorunu baş göstermekte, bu sorun belirli seviyeleri aştığında ise ülkeyi ekonomik krizlere sürükleyebilmektedir. Bu tür sorunlarla karşılaşmamak için yurtiçi tasarruf oranlarının artırılmasında, bunun için de fon sahiplerine, ellerindeki kaynakları etkin biçimde değerlendirebilecekleri finansal yatırım araçlarının sunulmasında ve bu yatırım araçları arasında doğru tercihler yapabilmeleri için kendilerine rehberlik edilmesinde yarar vardır.

Bu çalışmada, Türkiye'deki yatırımcıların kolay erişebildikleri dört finansal yatırım aracı (altın, borsa, döviz, faiz) arasındaki dinamik etkileşim analiz edilmiştir. Böylece söz konusu yatırım araçlarının getirileri arasında etkileşimin yönü ve büyüklükleri belirlenerek, yatırımcılara rehberlik edilmesine çalışılmıştır. Çalışmada, öncelikle korelasyon matrisi oluşturularak değişkenler arasındaki ikili ilişkilerin yönü ve büyüklüğü hakkında bir ön fikir elde edilmesi amaçlanmıştır. Bu matrise göre; altının getirisi ile dövizin getirisi arasında aynı yönlü ve güçlü, altının getirisi ile borsanın getirisi arasında zıt yönlü ve görece zayıf, altının getirisi ile faiz getirisi arasında ise aynı yönlü ancak oldukça zayıf ilişkilerin olduğu belirlenmiştir. Borsanın getirisi ile dövizin getirisi arasında zıt yönlü ve güçlü, borsanın getirisi ile faizin getirisi arasında zıt yönlü ve zayıf ilişkilerin olduğu tespit edilmiştir. Dövizin getirisi ile faizin getirisi arasında aynı yönlü fakat zayıf ilişki olduğu da görülmüştür. 
Çalışmanın ekonometrik analiz aşamasında dört farklı ekonometrik model kurulmuştur. Serilerin durağanlıkları; ADF ve PP yöntemleriyle test edilmiş ve bütün serilerin düzey değerlerinde durağan oldukları belirlenmiştir. Serilerin düzey değerleri kullanılarak kısıtsız bir VAR modeli tahmin edilmiştir. Elde edilen VAR modeline dayanarak, Etki - Tepki Fonksiyonları üretilmiş ve dövizin getirisinde meydana gelen bir artış şokuna karşılık; borsa, altın ve faiz ilk dönemde artış yönünde tepki vermiş olduğu, daha sonra altın ve faiz azalmaya geçtiği belirlenmiştir. Bu durumda yatırımcıların; dövizdeki artışı takip eden dönemde altın ve vadeli mevduattan döviz alımına doğru bir hareketlenme olabileceğini göz önünde bulundurmalarında yarar olduğuna karar verilmiştir.

Altının getirisinde meydana gelen bir artış şokuna karşılık; borsa, altın ve faiz ilk dönemde artış yönünde tepki vermiş, daha sonra döviz ve altının getirisi azalmaya başlamıştır. $\mathrm{Bu}$ durumda yatırımcıların; altın fiyatlarındaki artışı takip eden dönemde döviz ve vadeli mevduattan çıkıp, altın alımına yönelmelerinin mantıklı bir tercih olabileceği değerlendirilmektedir. Borsanın getirisinde meydana gelen bir azalış şokuna karşılık; altın, döviz ve faizin ilk dönemde artış yönünde tepki verdiği, daha sonra her üçünün de getirisinin artmaya başladı̆̆ bulunmuştur.

Bu sonuçlara göre; Türkiye'deki finansal piyasaların ilk etapta konjonktüre göre (birlikte) hareket ettiği, daha sonra düşen finansal yatırım aracının ikamesi (alternatifi) olan yatırım araçlarına yöneldikleri söylenebilir. Yatırımcıların da bu gerçeği göz önünde bulundurarak, yatırım sepetlerini çeşitlendirmelerinde yarar olduğu belirtilmelidir. Bu analizde son olarak vadeli mevduatların getirisinde (faizde) meydana gelen bir artış şokuna karşılık; borsa, altın ve dövizin getirisinin azalma yönünde tepki verdiği bulunmuştur. Demek ki borsa, altın ve döviz, Türkiye'de vadeli mevduatların açık bir ikamesidir. Yatırımcıların bu bilinçle hareket etmelerinde yarar vardır. Çalışmanın bu aşamasında elde edilen sonuçlar, literatürde yer alan: Levin vd. (2006); Balı ve Cinel (2011) ve Akbaş (2013) çalışmalarının bulgularıyla tutarlılık göstermektedir.

Tahmin edilen VAR modeline dayanarak gerçekleştirilen Varyans Ayrıştırması Analizinde; vadeli mevduatlardan elde edilen faiz getirisindeki değişimlerin \%54'ünün kendisinde meydana gelen değişimlerden, \%31'inin dövizin getirisinde meydana gelen değişimlerden, \%10.8'inin altının getirisindeki değişimlerden ve \%3.8'i borsanın getirisinde meydana gelen değişimlerden kaynaklandığı belirlenmiştir. Bu durumda vadeli mevduatın en önemli ikamesinin döviz olduğu söylenebilir. Yatırımcıların da portföylerini oluştururken, faizden sonra en büyük payı dövize ayırmaları, ussal bir davranış olacaktır.

Çalışmada, altının uzun vadeli bir yatırım aracı olduğu ve ortalama 23 ayda en yüksek getiriye ulaştı̆̆ 1 görülmüştür. $\mathrm{Bu}$ dönemde altının getirisinde meydana gelen değişimlerin \%86.9'unun kendisinden, \%10.2'sinin dövizden ve \%2.3'ünün borsada meydana gelen değişimlerden kaynaklandığı bulunmuştur. $\mathrm{Bu}$ sonuçlar, iki şeyi ortaya koymaktadır: Birincisi; altın fiyatlarının yurtiçi dinamiklerden çok, uluslararası dinamiklere göre şekillendiğini, ikincisi ise; uluslararası piyasalarda altın fiyatları dolar cinsinden belirlendiği ve işlem gördüğü için, dövizde meydana gelen değişimlerin altının yurtiçi satış fiyatlarını 
önemli ölçüde etkilediğidir. Dolayısıyla finansal yatırımcıların da bu hususlara dikkat etmelerinde yarar vardir.

Borsanın getirisinde yaşanan değişimlerin \%90.9'unun kendisinden, \%7.8'inin altının getirisinde meydana gelen değişimlerden kaynaklandığ 1 tespit edilmiştir. $\mathrm{Bu}$ durumda Türkiye'de İstanbul Menkul Kıymetler Borsası'nın en önemli ikamesi dövizdir. Yatırımcıların da portföylerini oluştururken, borsadan sonra en büyük payı dövize ayırmaları rasyonel bir davranış olacaktır. Çalışmada son olarak dövizin getirisinde meydana gelen değişimlerin kaynakları incelenmiş ve bu değişimlerin \%46.5'inin kendinden, \%38'inin altında meydana gelen değişimlerden, \%14'ünün borsada meydana gelen değişimlerden ve \%1.3'ünün de faizde meydana gelen değişimlerden kaynaklandığ görülmüştür. Bu durumda faiz getirisinin en önemli ikamesi dövizdir. Yatırımcıların da portföylerini oluştururken, borsadan sonra en büyük payı dövize ayırmaları mantıklı bir karar olacaktır. Çalışmanın bu aşamasında elde edilen sonuçlar, literatürde yer alan: Shahzadi ve Chohan (2012); Shaique, Aziz ve Herani (2016) ve Özkan ve Kolay (2016) çalışmalarının sonuçlarıyla uyumludur.

Çalışmada seriler arasındaki nedensellik ilişkileri Granger (1969) testi ile incelenmiş ve dövizden altına, altın, borsa ve dövizden faize ve borsadan dövize doğru tek yönlü nedensellik ilişkilerinin var olduğu belirlenmiştir. O halde, Türkiye'de bu finansal yatırım araçları birbirini etkilemektedirler. Yatırımcıların ve politika yapıcıların kararlarını, değişkenler arasındaki bu dinamik etkileşimleri göz önünde bulundurarak almalarında yarar vardır. Çalışmanın bu aşamasında elde edilen sonuçlar, literatürde yer alan: Elmas ve Esen (2011); Bhunia ve Mukhuti (2013) ve Güney ve Saka Ilgın (2019) çalışmalarının bulgularıyla uyumluluk göstermektedir.

$\mathrm{Bu}$ çalışmadan elde edilen bulgulara dayanarak; Türkiye'de altın, borsa, döviz ve faizin birbirinin ikamesi durumunda oldukları, yatırım sepetleri oluşturulurken, sahip olunan fonların bu finansal araçlar arasında dağıtılmasının yararlı olacağı, bu dağıtımda altının uzun vadede getiri sağlayacağının, borsa ve kısmen dövizin kısa dönemde de kâr kazandırabileceği, faizin düşük de olsa istikrarlı (garanti) bir getiri bekleyenler için ideal bir yatırım aracı olduğu söylenebilir. Çalışmadan elde edilen bulguların; hane halkı ve firma yöneticileri ile birlikte, bankalar, finansal aracı kurum temsilcileri ve politika yapıcılar için yol gösterici olması ve bu yönüyle literatüre ve ülke ekonomisine bir katkı sağlaması beklenmektedir. 


\section{KAYNAKÇA}

Akaike, H. (1974). A New Look at the Statistical Model Identification. IEEE Transactions on Automatic Control, 19 (6), $716-723$.

Akbaş, Y. E. (2013). Borsa Getiri Oranı ve Faiz Oranı Arasındaki İlişkinin Doğrusal Olmayan Yöntemlerle Analizi: Türkiye Örneği. Business and Economics Research Journal, 4(3), 21 - 40.

Balı, S. ve Cinel, M. (2011). Altın Fiyatlarının İMKB 100 Endeksi'ne Etkisi ve Bu Etkinin Ölçümlenmesi. Atatürk Üniversitesi IIIBF Dergisi, 25(3-4), 45 - 63.

Bhunia, A. and Mukhuti, S. (2013). The Impact of Domestic Gold Price on Stock Price Indices- an Empirical Study of Indian Stock Exchanges. Universal Journal of Marketing and Business Research, 2(2), 35 - 43.

Castro, T. B., Rodrigues, P. M. M. and Taylor, A. M. R. (2013). On the Behaviour of Phillips-Perron Tests in the Presence of Persistent Cycles. CEFAGE-UE Working Paper. No. 11.

Dickey, D. A. and Fuller, W. A. (1979). Distribution of the Estimators for Autoregressive Time Series with a Unit Root. Journal of the American Statistical Association, 74, 427 - 431.

Dickey, D. A. and Fuller, W. A. (1981). Distribution of the Estimators for Autoregressive Time Series with a Unit Root. Econometrica, 49, 1057 - 1072.

Doğan, N. (2018). Otomatik BES'ten Çıkan Yeniden Girecek. http://www.hurriyet.com.tr/yazarlar/noyandogan/otomatik-besten-cikan-yeniden-girecek-40998768, (Erişim Tarihi: 12.12.2019).

Domar J. D. (1946). Capital Expansion, Rate of Growth and Employment. Econometrica, 137 - 147.

Dursun, F. (2018). Temel İstatistik İşlemleri. https://fatihdursunn.wordpress.com/tag/korelasyon-matrisi/, (Erişim Tarihi: 10.02.2020).

Elmas, B. ve Esen, Ö. (2011). Hisse Senedi Fiyatları ile döviz Kuru Arasındaki Dinamik İlişkinin Belirlenmesi: Farklı Ülke Piyasaları İçin Bir Araştırma. Muhasabe ve Finansman Dergisi, 52, 153 - 170.

EVDS (2019a). Diş Borçlar, Diş Borçlar-Brüt (Hazine ve Maliye Bakanlığı)(Üç Aylık). https://evds2.tcmb.gov.tr/index.php?/evds/serieMarket, (Erişim Tarihi: 12.12.2019).

EVDS (2019b). Kurlar, Döviz Kurlar1, https://evds2.tcmb.gov.tr/index.php?/evds/serieMarket, (Erişim Tarihi: 12.12.2019)

EVDS (2019c). Faiz İstatistikleri, Bankalarca Açılan Mevduatlara Uygulanan Ağırlıklı Ortalama Faiz Oranları (Akım \%) (Haftalık). https://evds2.tcmb.gov.tr/index.php?/evds/serieMarket, (Erişim Tarihi: 12.12.2019).

EVDS (2019d). Altın Verileri, Altın Fiyatları (Ortalama) - Serbest Piyasa (TL)(Aylık). https://evds2.tcmb.gov.tr/index.php?/evds/serieMarket, (Erişim Tarihi: 12.12.2019).

Göçer, İ. (2013). Türkiye'de Cari Açı̆̆ın Nedenleri, Finansman Kalitesi ve Sürdürülebilirliğii: Ekonometrik Bir Analiz. Eskişehir Osmangazi Üniversitesi IİBF Dergisi, 8(1), 213-242.

Granger, C. W. J. (1969). Investigating Causal Relations by Econometric Models and CrossSpectral Methods. Econometrica, 37, 424 - 438.

Granger, C. W. J. ve Newbold, P. (1974). Spurious regressions in econometrics. Journal of Econometrics, Volume 2, Issue 2, July 1974, 111-120.

Güney, S. ve Saka Ilgın, K. (2019). Yatırım Araçlarının BIST-100 Endeksi Üzerindeki Etkisinin Değerlendirilmesi. Erciyes Üniversitesi İktisadi ve İdari Bilimler Fakültesi Dergisi, 53, 226 - 245.

Hannan, E. J., and Quinn, B. G. (1979). The Determination of the Order of an Autoregression. Journal of the Royal Statistical Society, Series B, 41, 190 - 195.

Harrod R. F. (1939). An Essay in Dynamic Theory. The Economic Journal, 49(193), 14 - 33.

IMF (2019). World Economic Outlook Database (October 2019). https://www.imf.org/external/pubs/ft/weo/2019/02/weodata/weorept.aspx? ?pr.x=58\&pr.y=6\&sy=1980\& $\mathrm{ey}=2019 \& \mathrm{scsm}=1 \& \mathrm{ssd}=1 \&$ sort=country $\& \mathrm{ds}=. \& \mathrm{br}=1 \& \mathrm{c}=186 \& \mathrm{~s}=\mathrm{NID}$ NGDP\%2CNGSD_NGDP\%2C BCA_NGDPD\&grp=0\&a=\#download, (Erişim Tarihi: 15.12.2019).

Levin, E. J., Montagnoli, A. and Wright, R. E. (2006). Short-Run and Long-Run Determinants of The Price of Gold. World Gold Council Research, No: 32.

Lucas, R. E. (1988). On the Mechanics of Economic Development. Journal of Monetary Economics, 22(4), 3-42. Markowitz, H. (1952). Portfolio Selection. Journal of Finance, 7(1), 77 - 91.

Mishra, P. K., Das, J. R. and Mishra, S. K. (2010). Gold Price Volatility and Stock Market Returns in India. American Journal of Scientific Research, 9, 47 - 55.

Newey W. K. and West K. D. (1994). Automatic Lag Selection in Covariance Matrix Estimation. The Review of Economic Studies, 61(4), 631 - 653.

Özkan, T. ve Kolay, Ç. (2016). Türkiye'de Altın Fiyatlarına Etki Eden Temel Faktörlerin Analizi. International Conference on Eurasian Economies 2016, https://www.avekon.org/papers/1728.pdf, (Erişim Tarihi: 16.12.2019).

Öztürk, N. ve Durgut, D. (2011). Faiz Oranlarının Belirleyicileri: Türkiye için Ampirik Bir Analiz. Uluslararası Alanya İsletme Fakültesi Dergisi, 3(1), 117 - 144. 
Phillips, P. C. B and Perron, P. (1988). Testing for a Unit Root in Time Series Regression. Biometrika, 75(2), 335 - 346.

Polat, M. A. (2019). Bankacıllk Sektörü Yurtiçi Kredi Hacmindeki Değişimlerin Cari Açı̆̆a Etkileri: Makro İhtiyati Tedbirler Kapsamında Ekonometrik Bir Analiz. Gazi İktisat ve İşletme Dergisi, 5(2), 73 - 89.

Romer, P. M. (1986). 'Increasing Returns and Long Run Growth. Journal of Political Economy, 94(5), $1002-$ 1037.

Schwarz, G. E. (1978). Estimating the Dimension of a Model. Annals of Statistics, 6 (2), 461 - 464.

Shaique, M., Aziz, A. and Herani, G. M. (2016). Impact of Gold Prices on Stock Exchange Market: A Case of Karachi Stock Exchange Market of Pakistan. International Journal of Accounting and Economics Studies, 4(1), $60-63$.

Shahzadi, H. and Chohan, M. N. (2012). Impact of Gold Prices on Stock Exchange: A Case Study of Pakistan. https://docplayer.net/11162827-Impact-of-gold-prices-on-stock-exchange-a-case-study-ofpakistan.html, (Erişim Tarihi: 15.12.2019).

Sims, C. A. (1980). Macroeconomics and Reality. Econometrica, 48, 1 - 48.

Sims, E. (2013). Graduate Macro Theory II: Notes on Time Series. https://www3.nd.edu/ esims1/time_series_notes_sp13.pdf, (Erişim Tarihi: 10.02.2020).

Solow, R. (1956). A Contribution to the Theory of Economic Growth. Quarterly Journal of Economics, 70(1), 65-94.

Swan, T. (1956). Economic Growth and Capital Accumulation. Economic Record, 32(63), 334-361.

Tapşın, G. (2011). İç Tasarruflar, Büyüme ve İstihdam İlişkisi. İstanbul Üniversitesi Sosyal Bilimler Enstitüsü Çalışma Ekonomisi ve Endüstri İlişkileri Anabilim Dalı, Yayımlanmamış Doktora Tezi.

TCMB (2013). Enflasyon ve Fiyat İstikrarı. Türkiye Cumhuriyet Merkez Bankası, ISBN (elektronik): 978-6054911-02-8.

TCMB (2015). Tasarruf - Yatırım Dinamikleri ve Cari İşlemler Dengesi Gelişmeleri. Türkiye Cumhuriyet Merkez Bankas1, ISBN (elektronik): 978-605-4911-35-6.

Tursoy, T. ve Faisal, F. (2017). The Impact of Gold and Crude Oil Prices on Stock Market in Turkey: Empirical Evidences from ARDL Bounds Test and Combined Cointegration. Resources Policy, 55, 49-54.

Yiğiter, Ş. Y. ve Akkaynak, B. (2017). Modern Portföy Teorisi: Alternatif Yatırım Araçları ile Bir Uygulama. KSÜ Sosyal Bilimler Dergisi, 14(2), 285- 300.

Zivot, E. (2011). Vector Autoregressive Models for Multivariate Time Series. https://faculty.washington.edu/ezivot/econ584/notes/varModels.pdf, (Erişim Tarihi: 10.02.2020). 